УДК 33:004

DOI: https://doi.org/10.26642/jen-2021-1(95)-17-22

К.В. Шиманська, д.е.н., доц.

В.В. Бондарчук, к.е.н., доц.

Державний університет «Житомирська політехніка»

\title{
Пріоритетні напрями та механізми розвитку цифрової економіки в Україні
}

Процес державотворення передбачає трансформацію всіх сфер життя суспільства, в тому числі й економічних відносин. Розвиток ичифрової економіки Украӥни лише набирає обертів, i важливо правильно обрати напрям та інструменти ї̈ формування. Цифровізація економіки відбувається одночасно на макро- $i$ мікрорівні. Необхідно будувати иифрове середовище національної економіки таким чином, щоб воно задовольняло потреби не лиме держави в особі державних інституиій, але й громадян та бізнесу.

Дослідження формування і розвитку циифровізації економіки Украӥни показало, щяо цей процес має сильні та слабкі сторони. Використання сильних сторін може суттєво пришвидшити цифровізацію та забезпечити економічні вигоди для всіх суб' єктів економічних відносин в Україні. Цьому сприяють і наявні в нашій державі можливості. Проте необхідно також працювати над нівелюванням слабких сторін та вживати заходи щзодо мінімізації загроз для цифровізаціі економіки. Запропоновані механізми цифровізації можуть забезпечити поступове впровадження цифррових технологій у стратегічних галузях вітчизняної економіки, які є фундаментом для подальшого процесу циирровізачії. Необхідно створити такі умови, коли циифровізація є бажаною та забезпечує конкурентні переваги для бізнесу і зручність для споживачів. У такому випадку формування цииррової економіки в Украӥні відбуватиметься з ініціативи бізнесу та громадськості, які і є основними бенефіціарами изього процесу.

Ключові слова: ичифровізація; механізми ичифровізації; інструменти цุифровізації; цฺифрова економіка; ичиррова трансформачія.

Актуальність теми. Процес державотворення передбачає трансформацію всіх сфер життя суспільства, в тому числі й економічних відносин. Не $є$ виключенням тенденції цифрової трансформації, які вимагають переосмислення значення цифрових технологій для досягнення цілей розвитку суспільства. Зокрема, всі значущі трансформації у світовій економіці були пов'язані зі змінами технологічних укладів від аграрної економіки сталості до індустріальної епохи з «економікою відкриттів» і далі до нинішньої цифрової епохи, яку сміливо можна пов'язати з «економікою змін». Розвиток цифрової економіки України лише набирає обертів, і важливо правильно обрати напрям та інструменти ії формування. Цифровізація економіки відбувається одночасно на макро- і мікрорівні. Необхідно будувати цифрове середовище національної економіки таким чином, щоб воно задовольняло потреби не лише держави в особі державних інституцій, але й громадян та бізнесу. При цьому важливо не змушувати до цифровізації, а створити умови, в яких цифровізація забезпечує конкурентні переваги тим, хто до неї долучається. Лише в цьому випадку формування цифрової економіки конвертується в економічне зростання. Тому актуалізуються питання інституційного забезпечення та побудови дієвих механізмів розвитку цифрової економіки України, здатної адаптуватися до нових викликів і загроз глобального цифрового простору.

Аналіз останніх досліджень і публікацій, на які спираються автори. Питання розвитку цифрової економіки в Україні є відносно новим та малодослідженим. Теоретичні аспекти цифрової економіки описано у дослідженні Л.О. Матвейчук [8]. Передумови для цифровізації економіки розглянуто у дослідженні Г.І. Жекало [4], вплив цифровізації на розвиток національної та міжнародної економіки досліджували Г.Т. Карчева, Д.В. Огородня, В.А. Опенько [6], І.Б. Шевчук, Б.Я. Депутат, О.Є. Тарасенко [11]. Сучасний стан цифровізації в Україні досліджували Н.Ю. Подольчак, О.І. Білик, Я.В. Левицька [10], тренди та перспективи розвитку цифрової економіки розкрито у дослідженні Н.М. Краус, О.П. Голобородько, К.М. Краус [7]. Особливості формування та розвитку цифрової економіки в Україні досліджували Т.І. Батракова, В.Ю. Линовець [1], В.К. Загарій, Т.Г. Ковальчук, В.В. Синільник [5]. Попри наявні дослідження, що стосуються різних аспектів формування цифрової економіки України, залишається невирішеною низка питань, зокрема, визначення найбільш першочергових векторів цифровізації економіки України та їі механізмів, що доступні на сучасному етапі розвитку економіки нашої держави.

Метою статті є визначення пріоритетних векторів та механізмів цифрової трансформації економіки України.

Викладення основного матеріалу. Реалізація стратегії з цифровізації економіки не може бути нав'язана державою як директива. Будь-які інновації впроваджуються на мікрорівні суб'єктів господарювання за їх власною ініціативою, а держава може допомогти цьому процесу, створивши 
сприятливі умови для впровадження цифрових технологій в економічне життя суспільства. Впровадження інформаційних технологій у діяльність українського бізнесу сьогодні має низку перешкод системного характеру. Насамперед вважаємо за доцільне виокремити елементи цифровізації економіки, які слід розглянути в контексті цього дослідження (рис. 1).

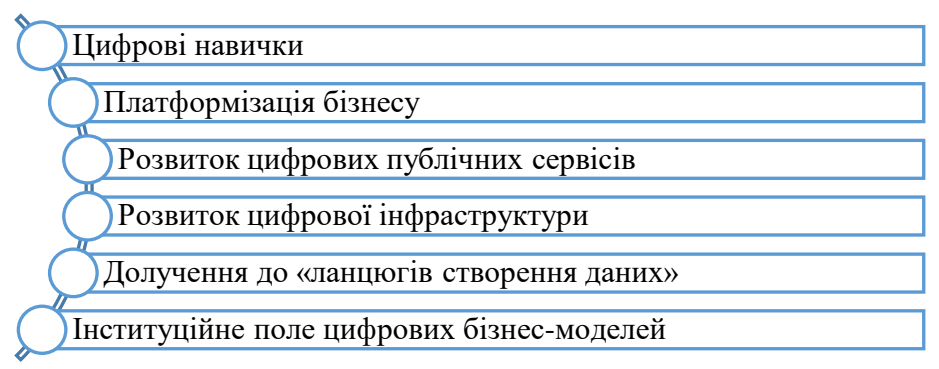

Рис. 1. Елементи цฺифровізації економіки

Розглянемо їх детальніше 3 погляду розвитку цифрової економіки України. Цифровізація бізнеспроцесів компаній вимагає динамічного розвитку цифрових навичок. Якщо цифрова трансформація компаній $є$ швидкою, а переважна більшість працівників не має відповідних навичок роботи у цифровому середовищі реалізації професійних функцій, працівники намагаються працевлаштуватися у менш цифровізованих галузях або й у інших країнах. Тобто в короткостроковій перспективі це спровокує нестачу кадрів на внутрішньому ринку та відплив працівників 3 країни. За результатами дослідження [12] 37,9 \% українців мають цифрові навички на рівні нижче середнього, а 15,1% не мають їх взагалі.

Долучення країни до так званих глобальних «ланцюгів створення даних» $є$ неможливим за існуючих структурних пропорцій національної економіки, адже превалювання сільськогосподарського експорту, який становить 48 \% від сукупного експорту [3], та пільгові митні умови у зовнішньоторговельних відносинах знижують мотивацію національних виробників до переорієнтації у більш інноваційні та технологічні сектори економіки.

Тенденція платформізації наразі не відповідає існуючим моделям використання інформаційнокомп'ютерних технологій, мережі Інтернет та хмарних сервісів українськими компаніями, особливо малим та середнім бізнесом. Так спостерігається низький рівень використання хмарних сервісів, примітивний цифровий функціонал сайтів переважної частини представників малого бізнесу, а також нерозуміння пересічними представниками бізнесу цінності накопичення даних та шляхів їх монетизації. У 2019 році ринок хмарних сервісів в Україні становив 29 млн дол. (для порівняння, компанія «Аррlе» в місяць витрачає на хмарні сервіси більше 30 млн дол.) [1]. Хоча потенціал використання зарубіжних платформ національними компаніями для розвитку експортного потенціалу важко переоцінити.

Також можна констатувати неготовність інфраструктури та інституційного поля соціального й адміністративного обслуговування населення до цифрової трансформації. Наразі всі ініціативи Міністерства цифрової трансформації України йдуть від самого міністерства, роблячи його центром цифрових інновацій громадського сектору. Проте найнижчі та середні ланки інших сфер державного управління не дають як стейкхолдери запит на такі трансформації. Причин є багато: забюрократизованість, консервативність, низька мотивація працівників до змін, адже такі зміни означають вихід усієї системи «із зони комфорту». Тобто в цілому соціальні та економічні вигоди від розвитку цифрової економіки будуть залежати від рівня розвитку країни та цифрової готовності її стейкхолдерів. Якщо суспільство формуватиме запит на цифрову трансформацію і цифровізація почнеться із громадського сектору, то населення як споживач товарів та послуг буде висувати інший рівень вимог до українських компаній. Саме тоді бізнес відреагує та імплементує цифрову трансформацію у стратегію побудови конкурентоспроможної бізнес-моделі.

Наразі цифровізація в Україні демонструє високі показники розвитку, що до 2030 року дозволить збільшити ВВП на 4 \% [9]. Окремі сектори економіки, зокрема сектор адміністративних послуг, цифровізували частину функцій та віртуалізували частину взаємодії з користувачами. Проте застаріле інституційне поле в багатьох секторах економіки стає бар'єром ефективного впровадження цифрових технологій. Нормативно-правові засади роботи організацій та органів влади ситуативно «латаються» під нові цифрові рішення. I якими би вони інноваційними не були, концепції їх впровадження й відповідні законодавчі акти слід розробляти «з нуля», керуючись іншими моделями суспільної взаємодії.

Якщо розглядати цифровізацію економіки України як функціональне явище (яке є похідним від приватних та суспільних інтересів), то можна виокремити сильні та слабкі сторони процесу цифровізації, а також можливості й загрози для іiі розвитку. До сильних сторін цифровізації належить географічна присутність України на міжнародних ринках товарів і послуг. Це визначає можливість інтеграції цифрової взаємодії в існуючі міжнародні економічні відносини. Також сюди належить присутність компаній 
України у цифровому просторі соціальних мереж, що забезпечує просування на ринок товарів та послуг і $\epsilon$ майданчиком для спілкування зі своїми клієнтами для вітчизняного бізнесу. Нівелювання меж національного та зростання глобального взаємозв'язку дозволяють компанії вийти на міжнародний ринок і спрямувати зусилля на географічно розподілену клієнтську базу, підвищити прибутковість. В Україні також досить широкий доступ населення до мережі Інтернет, що $є$ гарною передумовою для широкомасштабного впровадження цифрових технологій. Щоправда швидкість інтернету відрізняється у різних населених пунктах України, зокрема у сільській місцевості та районах.

Слабкими сторонами цифровізації в Україні є те, що:

- вітчизняні компанії не можуть масштабно фінансувати проєкти цифровізації бізнес-процесів;

- бізнес-моделі українських компаній переважної частини галузі пристосовані до аналогового формату ведення бізнесу та складно трансформуються й адаптуються до цифрового середовища;

- компанії не достатньо компетентні щодо контент-менеджменту, що знижує потенціал ефективності використання соціальних мереж та SMM;

- $\quad$ компанії переважно не бачать цінності в акумулюванні та аналізі даних, хоча потенційно такі дані накопичуються на основі онлайн-активності користувачів сайту компаній.

Вважаємо, що така ситуація спричинена тим, що в Україні наразі не надто розповсюджена стратегія аналізу онлайн-середовища як одного з ключових джерел інформації про зовнішнє середовище бізнесу. Крім цього, до слабких сторін належить брак кваліфікованої робочої сили з потужними цифровими навичками на ринку праці, що може ускладнити для організації залучення талантів із належним набором вмінь, а також відсутність цифрової трансформації у стратегічних цілях компанії. 3 цим пов'язана в подальшому неефективність стилю керівництва організації та безсистемна цифрова трансформація.

Разом 3 тим, існують можливості, які наразі відкриті до реалізації і можуть забезпечити стрімкий розвиток цифровізації економіки, зокрема цифрове «стирання кордонів» внаслідок розвитку інтернеткомерції, що потенційно дає можливості знизити бар'єри виходу українських компаній на міжнародні ринки. Водночас зростають обсяги відкритих даних у світі, які можуть бути використані для планування та прогнозування діяльності компанії, а транснаціональне поширення бізнес-ланцюгів, мережевізація економіки дає змогу компаніям України долучитися до глобальних ланцюгів створення вартості (у секторі матеріальних благ) і стати частиною «ланцюгів створення вартості даних». Крім того, розробка нових технологій для сприяння виробництву та постачанню продукції / послуги може бути використана для впровадження інновацій у ділові операції. Прогресивна технологічна інтеграція може зменшити витрати, підвищити ефективність та швидко призвести до впровадження інноваційних продуктів. Виникнення нових сегментів ринку і нових ніш також надають можливості для бізнесу та розширення товарної лінійки.

До загроз розвитку процесу цифровізації економіки України зараховують:

- зростання глобальних кіберзагроз для національних суб'єктів бізнесу;

- потребу модернізації національної інформаційної та телекомунікаційної інфраструктури, розширення доступу до неї компаній (незалежно від їх розміру);

- більш жорсткі вимоги міжнародних нормативних актів 3 питань цифрової трансформації та імплементації цифрових технологій у громадський сектор і галузі економіки;

- погіршення економічних умов як в Україні, так і в світовій економіці, що впливає на погіршення результатів діяльності бізнесу, зниження можливості фінансування інвестицій та інновацій, втрата купівельної спроможності споживачів;

- те, що клієнти можуть почати віддавати перевагу новим та креативним продуктам / послугам в результаті зміни смаку.

Варто зазначити, що ці загрози актуальні не лише для нашої економіки, але й для решти країн світу, тому вироблення механізмів захисту від цих загроз також є стратегічним завданням для полісімейкерів під час формування адженди цифровізації.

3 огляду на розглянуті сильні сторони та можливості цифровізації вважаємо, що пріоритетними векторами цифровізації економіки України мають стати:

1) побудова діалогу між стейкхолдерами для визначення функціональних запитів та пріоритетних сфер, взаємодія у яких має бути цифровізована у першу чергу. Це дозволить знизити опір впровадженню цифрових рішень у сферу економіки, громадський сектор тощо, а також скерувати цифрові інновації на зниження асиметрії у доступі до благ, досягнення окремих цілей сталого розвитку, і як наслідок, підвищення рівня добробуту;

2) розвиток цифрових навичок населення в цілому для застосування цифрових сервісів громадянського суспільства та розвиток цифрових навичок фахівців для володіння професійними цифровими технологіями. В цьому аспекті необхідно модернізувати навчальні плани підготовки фахівців всіх спеціальностей та популяризувати і розширити можливості отримання цифрових навичок населенням;

3) розвиток цифрових навичок для ведення бізнесу (робота 3 відкритими даними, цифровими адміністративними послугами, застосування електронних ключів, засад кібербезпеки, цифровізації документообігу). 
Очевидно, що для практичного впровадження всіх зазначених векторів цифровізації необхідні дієві інструменти. Враховуючи особливості цифрового середовища та цифрової інфраструктури вітчизняної економіки, вважаємо, що для реалізації стратегічних цілей цифровізації можна використати інструменти, представлені в таблиці 1.

Інструменти та механізми для розвитку ичифрової економіки в Украӥні

Таблиияя 1

\begin{tabular}{|c|c|c|}
\hline Стратегічні цілі & Механізми & Інструменти \\
\hline $\begin{array}{l}\text { Побудова діалогу між } \\
\text { стейкхолдерами } \\
\text { цифрової економіки } \\
\text { (держава в особі } \\
\text { окремих органів, } \\
\text { громадяни, бізнес, } \\
\text { галузеві об'єднання) }\end{array}$ & $\begin{array}{l}\text { 1. Громадські } \\
\text { консультації та } \\
\text { робота зі } \\
\text { стейкхолдерами }\end{array}$ & $\begin{array}{l}\text { 1. Робота фокус-груп. } \\
\text { 2. Презентація та громадське обговорення } \\
\text { проєктів нормативно-правових документів } 3 \\
\text { питань цифрової трансформації. } \\
\text { 3. Залучення стейкхолдерів на етапі проєктування } \\
\text { та перегляду регуляторних актів. } \\
\text { 4. Всеукраїнські або регіональні опитування } \\
\text { різних категорій стейкхолдерів як засіб } \\
\text { моніторингу ефективності реформ }\end{array}$ \\
\hline $\begin{array}{c}\text { Розвиток цифрових } \\
\text { навичок }\end{array}$ & $\begin{array}{l}\text { 1. Бюджетна політика. } \\
\text { 2. Комунікаційна та } \\
\text { інформаційна } \\
\text { політика. } \\
\text { 3. Економічна } \\
\text { політика }\end{array}$ & $\begin{array}{l}\text { 1. Популяризація цифрових навичок серед } \\
\text { населення, проведення роз'яснювальної роботи } \\
\text { (онлайн-інструкції, особисті консультації тощо) } \\
\text { щодо використання громадських цифрових } \\
\text { сервісів. } \\
\text { 2. Фінансування видатків на навчання громадян } \\
\text { основам цифрової грамотності, підготовку } \\
\text { відповідних інформаційних матеріалів, } \\
\text { облаштування цифрових освітніх хабів. } \\
\text { 3. Фінансування / організація навчання } \\
\text { представників бізнесу, особливо МСП, щодо: } \\
\text { - роботи на міжнародних онлайн-платформах та } \\
\text { використання міжнародних інформаційних баз; } \\
\text { - роботи з об'єктами прав інтелектуальної } \\
\text { власності у цифровій економіці. } \\
\text { 4. Пілотні проєкти для ОТГ з розвитку цифрових } \\
\text { навичок управління громадою }\end{array}$ \\
\hline $\begin{array}{c}\text { Стимулювання бізнесу } \\
\text { щодо впровадження } \\
\text { цифрових технологій }\end{array}$ & $\begin{array}{l}\text { 1. Фіскальна політика. } \\
\text { 2. Політика } \\
\text { зайнятості. } \\
\text { 3. Економічна } \\
\text { політика }\end{array}$ & $\begin{array}{l}\text { 1. Надання податкових пільг компаніям, які } \\
\text { створюють цифровізовані робочі місця, } \\
\text { вкладають кошти у модернізацію програмного } \\
\text { забезпечення, що використовується для } \\
\text { надання послуг населенню, впроваджують } \\
\text { SMART-технології управління ресурсами } \\
\text { (в т. ч. відходами виробництва та } \\
\text { енергозберігаючими технологіями). } \\
\text { 2. Зниження відсоткових ставок податків під час } \\
\text { використання послуг міжнародних } \\
\text { торговельних платформ (імпорт послуг) }\end{array}$ \\
\hline
\end{tabular}

Варто розуміти, що, попри прагнення влади та лідерів думок до стрімкої цифровізації всіх аспектів економіки України, швидким цей процес не буде. Насамперед необхідно впроваджувати цю технологію в освіту та громадський сектор. Це можна зробити через:

1) цифровізацію адміністративних послуг, що пристосує громадян до цифрового середовища взаємодії. Саме вони мають стати носіями принципів і цінностей цифрової трансформації та формувати запити до бізнесу й органів влади;

2) розробку механізмів та середовища дистанційного навчання й електронного адміністрування освітніх процесів, що має бути зроблено на всіх рівнях;

3) розвиток інфраструктури телекомунікацій у регіонах України, що дасть змогу локальному бізнесу стати частиною ланцюгів створення вартості;

4) фінансування / організацію навчання представників бізнесу, особливо МСП, щодо роботи на міжнародних онлайн-платформах та використання міжнародних інформаційних баз (подібні програми вже реалізуються Офісом просування експорту, Укрпоштою, платформою «Дія. Цифрова освіта»); 
5) фінансування / організацію навчання представників бізнесу, особливо МСП, щодо роботи 3 об'єктами прав інтелектуальної власності, промисловими зразками, торговельними марками та географічними зазначеннями.

Запорукою успішної цифровізації економіки України є поступове та клієнтоорієнтоване впровадження цифрових технологій. Коли цифровізація забезпечуватиме комфорт та переваги для іiі користувачів, лише тоді дійсно відбудеться цифрова революція в нашій державі, а реформа цифровізації дійсно стане реформою, що докорінно змінить українську економіку.

Висновки та перспективи подальших досліджень. Дослідження формування та розвитку цифровізації економіки України показало, що цей процес має сильні та слабкі сторони. Використання сильних сторін може суттєво пришвидшити та забезпечити цифровізацію для всіх суб'єктів економічних відносин в Україні. Цьому сприяють і наявні в нашій державі можливості. Проте необхідно також працювати над вирішенням слабких сторін та вживати заходи щодо мінімізації загроз для цифровізації економіки. Запропоновані механізми цифровізації можуть забезпечити поступове впровадження цифрових технологій у стратегічних галузях вітчизняної економіки, які $є$ фундаментом для подальшого процесу цифровізації. Також не варто очікувати швидкого переходу всієї економіки в цифрове середовище, оскільки це неможливо. Але можливо створити такі умови, коли цифровізація є бажаною та забезпечує конкурентні переваги для бізнесу і зручність для споживачів. У такому випадку формування цифрової економіки в Україні відбуватиметься 3 ініціативи бізнесу та громадськості, які і $\epsilon$ основними бенефіціарами цього процесу.

\section{Список використаної літератури:}

1. Агеєв М. Ринок хмарних сервісів в Україні в 2020 році / М.Агеєв // Інтерфакс Україна. - 2020 [Електронний pecypc]. - Режим доступу : https://ua.interfax.com.ua/news/blog/708733.html.

2. Батракова T.I. Особливості та принципи цифрової економіки в Україні / T.I. Батракова, В.Ю. Линовець // Економічні студії. - 2018. - № 2 (20) [Електронний ресурс]. - Режим доступу : https://journals.indexcopernicus.com/api/file/viewByFileId/623580.pdf.

3. Вінокуров Я. Частка сільськогосподарських товарів сягнула 48 \% всього експорту - Мінекономіки / Я.Вінокуров // Громадське. - 2020 [Електронний ресурс]. - Режим доступу : https://hromadske.ua/posts/chastkasilskogospodarskih-tovariv-syagnula-48-vsogo-eksportu-minekonomiki.

4. Жекало Г.І. Цифрова економіка України: проблеми та перспективи розвитку / Г.І. Жекало // Науковий вісник Ужгородського національного університету. - 2019. - Вип. 26, Ч. 1 [Електронний ресурс]. - Режим доступу : http://www.visnyk-econom.uzhnu.uz.ua/archive/26_1_2019ua/12.pdf.

5. Загарій В.К. Пріоритетність розвитку цифрової економіки для України / В.К. Загарій, Т.Г. Ковальчук, B.B. Синільник // Приазовський економічний вісник. - 2019. - Вип. 2 (13) [Електронний ресурс]. - Режим доступу : http://pev.kpu.zp.ua/journals/2019/2_13_uk/13.pdf.

6. Карчева Г.Т. Цифрова економіка та їі вплив на розвиток національної та міжнародної економіки / Г.Т. Карчева, Д.В. Огородня, В.А. Опенько // Фінансовий простір. - 2017. - № 3 (27) [Електронний ресурс]. Режим доступу : https://ofp.cibs.ubs.edu.ua/files/1703/17kgttme.pdf.

7. Краус Н.М. Цифрова економіка: тренди та перспективи авангардного характеру розвитку / Н.M. Краус, О.П. Голобородько, К.М. Краус // Ефективна економіка. - 2018. - № 1 [Електронний ресурс]. - Режим доступу : http://www.economy.nayka.com.ua/pdf/1_2018/8.pdf.

8. Матвейчук Л.О. Цифрова економіка: теоретичні аспекти / Л.О. Матвейчук // Вісник Запорізького національного університету. - 2018. - № 4 (40) [Електронний ресурс]. - Режим доступу : http://visnykznu.org/issues/2018/2018-econ-4/20.pdf.

9. Михайло Федоров: Цифровізація економіки дозволить досягти мінімум $4 \%$ додаткового зростання ВВП на рік // Міністерство та комітет цифрової трансформації України. - 2021 [Електронний ресурс]. - Режим доступу : https://thedigital.gov.ua/news/mihajlo-fedorov-cifrovizaciya-ekonomiki-dozvolit-dosyagti-minimum-4dodatkovogo-zrostannya-vvp-na-rik.

10. Подольчак Н.Ю. Сучасний стан цифровізації в Україні / Н.Ю. Подольчак, О.І. Білик, Я.В. Левицька // Ефективна економіка [Електронний ресурc]. - Режим доступу : http://www.economy.nayka.com.ua/pdf/10_2019/6.pdf.

11. Шевчук І.Б. Цифровізація та її вплив на економіку України: переваги, виклики, загрози й ризики / І.Б. Шевчук, Б.Я. Депутат, О.С. Тарасенко // Причорноморські економічні студії. - 2019. - Вип. 47-2 [Електронний pecypc]. - Режим доступу : http://bses.in.ua/journals/2019/47_2_2019/34.pdf.

12. Digital Literacy of the Population of Ukraine / Ministry of Digital Transformation of Ukraine. - 2019 [Електронний pecypc]. - Режим доступу : the_first_in_the_history_of_ukraine_research_compressed.pdf.

\section{References:}

1. Agejev, M. (2020), «Rynok hmarnyh servisiv v Ukrai'ni v 2020 roci», Interfaks Ukrai'na, [Online], available at: https://ua.interfax.com.ua/news/blog/708733.html

2. Batrakova, T.I. and Lynovec', V.Ju. (2018), «Osoblyvosti ta pryncypy cyfrovoi' ekonomiky v Ukrai'ni», Ekonomichni studii', No. 2 (20), [Online], available at: https://journals.indexcopernicus.com/api/file/viewByFileId/623580.pdf 
3. Vinokurov, Ja. (2020), «Chastka sil's'kogospodars'kyh tovariv sjagnula 48 \% vs'ogo eksportu - Minekonomiky», Gromads'ke, [Online], available at: https://hromadske.ua/posts/chastka-silskogospodarskih-tovariv-syagnula-48vsogo-eksportu-minekonomiki

4. Zhekalo, G.I. (2019), «Cyfrova ekonomika Ukrai'ny: problemy ta perspektyvy rozvytku», Naukovyj visnyk Uzhgorods'kogo nacional'nogo universytetu, Issue 26, Part 1, [Online], available at: http://www.visnykeconom.uzhnu.uz.ua/archive/26_1_2019ua/12.pdf

5. Zagarij, V.K., Koval'chuk, T.G. and Synil'nyk, V.V. (2019), «Priorytetnist' rozvytku cyfrovoi' ekonomiky dlja Ukrai'ny», Pryazovs'kyj ekonomichnyj visnyk, Issue 2 (13), [Online], available at: http://pev.kpu.zp.ua/journals/2019/2_13_uk/13.pdf

6. Karcheva, G.T., Ogorodnja, D.V. and Open'ko, V.A. (2017), «Cyfrova ekonomika ta i'i' vplyv na rozvytok nacional'noi' ta mizhnarodnoi' ekonomiky», Finansovyj prostir, No. 3 (27), [Online], available at: https://ofp.cibs.ubs.edu.ua/files/1703/17kgttme.pdf

7. Kraus, N.M., Goloborod'ko, O.P. and Kraus, K.M. (2018), «Cyfrova ekonomika: trendy ta perspektyvy avangardnogo harakteru rozvytku», Efektyvna ekonomika, No. 1, [Online], available at: http://www.economy.nayka.com.ua/pdf/1_2018/8.pdf

8. Matvejchuk, L.O. (2018), «Cyfrova ekonomika: teoretychni aspekty», Visnyk Zaporiz'kogo nacional'nogo universytetu, No. 4 (40), [Online], available at: http://visnykznu.org/issues/2018/2018-econ-4/20.pdf

9. Ministerstvo ta komitet cyfrovoi' transformacii' Ukrai'ny (2021), «Myhajlo Fedorov: Cyfrovizacija ekonomiky dozvolyt' dosjagty minimum $4 \%$ dodatkovogo zrostannja VVP na rik», [Online], available at: https://thedigital.gov.ua/news/mihajlo-fedorov-cifrovizaciya-ekonomiki-dozvolit-dosyagti-minimum-4dodatkovogo-zrostannya-vvp-na-rik

10. Podol'chak, N.Ju., Bilyk, O.I. and Levyc'ka, Ja.V., «Suchasnyj stan cyfrovizacii' v Ukrai'ni», Efektyvna ekonomika, [Online], available at: http://www.economy.nayka.com.ua/pdf/10_2019/6.pdf

11. Shevchuk, I.B., Deputat, B.Ja. and Tarasenko, O.Je. (2019), «Cyfrovizacija ta i'i' vplyv na ekonomiku Ukrai'ny: perevagy, vyklyky, zagrozy j ryzyky», Prychornomors'ki ekonomichni studii', Issue 47-2, [Online], available at: http://bses.in.ua/journals/2019/47_2_2019/34.pdf

12. Ministry of Digital Transformation of Ukraine (2019), Digital Literacy of the Population of Ukraine, [Online], available at: https://osvita.diia.gov.ua/uploads/0/588-the_first_in_the_history_of_ukraine_research_compressed.pdf

Шиманська Катерина Володимирівна - доктор економічних наук, завідувач кафедри цифрової економіки та міжнародних економічних відносин Державного університету «Житомирська політехніка». https://orcid.org/0000-0003-0375-5102.

Наукові інтереси:

- міжнародна торгівля та проблеми ії регулювання;

- цифрова трансформація економіки.

Бондарчук Віталій Вікторович - кандидат економічних наук, доцент кафедри цифрової економіки та міжнародних економічних відносин Державного університету «Житомирська політехніка».

https://orcid.org/0000-0001-8156-0218.

Наукові інтереси:

- проблеми міжнародної економіки;

- циклічність економічного розвитку;

- вплив монетарної політики на економічне зростання. 